\title{
PSYCHOLOGICAL RISK FACTORS FOR CARDIOVASCULAR DISEASES
}

DOI: 10.36740/WLek202009104

\author{
Alicja Nasiłowska-Barud', Małgorzata Barud² \\ 'DEPARTMENT OF CLINICAL PSYCHOLOGY, MEDICAL UNIVERSITY, LUBLIN, POLAND \\ 2DEPARTMENT OF ANAESTHESIOLOGY AND INTENSIVE CARE, MEDICAL UNIVERSITY, LUBLIN, POLAND
}

\begin{abstract}
Introduction: Cardiovascular diseases are one of the most important causes of the morbidity and mortality in the Polish and European population, accounting for nearly half of the causes of death. Prevention and treatment of cardiovascular diseases, especially in view of the predicted increase in mortality rate as a result of these diseases in the aging populations is crucial.

The aim: To characterize selected psychological risk factors that predispose to the development of cardiovascular disease.

Review and disscusion: Numerous scientific studies indicate the importance of mental and psychosocial factors in the prevention, treatment and rehabilitation patients with cardiovascular diseases. In this article the most important psychological risk factors, such as Type A and D personality, stress, depression and depressed mood, anxiety, social support and lifestyle are presented.

Conclusions: Population-focused programs devoted to health promotion and informing the general public about the risk factors for cardiovascular diseases should mainly aim at improving people's lifestyle, in particular with regard to nutrition, smoking, alcohol consumption, physical activity and mental well-being.
\end{abstract}

KEY WORDS: risk factors, type A personality, type D personality, depression, anxiety, social support, lifestyle

Wiad Lek. 2020;73(9 p. I):1829-1834

\section{INTRODUCTION}

The scientific study of risk factors for cardiovascular diseases and other diseases dates back to the first half of the 20th century. After the Second World War, a dramatic increase in morbidity and mortality from myocardial infarction and stroke was observed in the United States. The epidemiological situation in the US inspired scientists to search for the causes of this phenomenon. Researchers wanted to know what individual and environmental causes could have contributed to the increased incidence of diseases secondary to atherosclerosis $[1,2]$.

In 1948, the first long-term prospective epidemiological study was launched in the American town of Framingham with a sample of several thousand of the town's inhabitants. The Framingham Heart Study (FHS) allowed to determine the prevalence, incidence and mortality of coronary heart disease and introduced the concept of risk factors. Similar analyses involving very large populations of people were later carried out in other US towns and cities and in many European countries, including Poland. The FHS has been run for over 70 years and is still an open and ongoing project [3-5].

Kannel, Friedman and Rosenman, the main authors of the FHS, initially identified four factors associated with the development of atherosclerotic lesions: heavy smok- ing, hypertension, hyperlipidemia and diabetes. In 1972, researchers established about forty other risk factors and since that time the number of newly discovered factors has been growing. Scientific publications from the 1990s mention 248 factors, and recent reports list about 300 factors that can lead to cardiovascular diseases [6-8].

Given such a large number of risk factors, they obviously needed to be classified. The basic division of risk factors is based on the criterion of modifiability. A modifiable risk factor is one whose deleterious atherosclerotic effects can be reduced by external interventions. According to this classification, the first group of factors are non-modifiable factors that are not susceptible to change and cannot be subjected to any external influences that could change their atherosclerotic effects.

Research indicates that the occurrence of risk factors for cardiovascular diseases and the level of their severity are related to gender, and therefore there are some differences between women and men [9-11].

\section{THE AIM}

The aim of the study was to characterize selected psychological risk factors that predispose to the development of cardiovascular disease. 


\section{REVIEW AND DISSCUSION}

Non- Modifiable cardiovascular risk factors include age (men $\geq 45$ years, women $\geq 55$ years), gender (higher risk in men than in pre-menopausal women), family history of cardiovascular diseases (coronary heart disease or stroke in direct-line family members), and co-morbidities (kidney diseases, thyroid diseases, metabolic disorders). Some of the recently discovered cardiovascular risk factors include increased plasma concentrations of C-reactive protein (CRP), homocysteine, lipoprotein (a) and fibrinogen.

A second group of risk factors are modifiable factors which can be controlled and whose harmful effects can be reduced by making changes to one's behavior and lifestyle. The knowledge that one can prevent the disease by modifying one's behavior should strongly motivate individuals to adopt health promoting behaviors. Modifiable cardiovascular risk factors include poor nutrition, smoking, low physical activity, increased blood pressure, increased plasma LDL-cholesterol (LDL-C), low plasma HDL-cholesterol (HDL-C), increased plasma triglyceride (TG), impaired glucose tolerance or diabetes, overweight and obesity.

In recent years, there has been an increase in the number of psychosocial factors contributing to the development of cardiovascular diseases. The most frequently mentioned among these is personality, especially type A personality (type A behavior pattern). However, scientific research of the last twenty years also points to type $\mathrm{D}$ personality (type $\mathrm{D}$ behavior pattern), depression (chronically depressed mood), anxiety, stress at work and in family life, isolation, low social support, and low socioeconomic position as risk factors for this class of diseases $[12,13]$.

\section{TYPE A PERSONALITY AS A RISK FACTOR FOR CORONARY HEART DISEASE}

Some characteristic features of behavior of patients with heart diseases were already discerned by mid-nineteenth century physicians. In 1868, German physician von Deutsch described the characteristics of patients with angina pectoris. The most prominent of these were rapid and loud speech, overworking, arousal, heavy smoking, overeating and overweight [14-16].

At the beginning of the twentieth century, Osler characterized patients with heart diseases as aggressive, overly involved in their work, and highly ambitious, with ambition leading to excessive activity and long working hours. He believed that there was a connection between personality and cardiovascular diseases. It should be noted that the first description of personality traits of cardiac patients written by Osler served as a hypothesis on which the concept of type A personality was based. A similar characterization of patients with heart diseases was given in the 1930s by the Menningers and in the 1940s by Dunbar [14].

In the early 1950s, a longitudinal clinical study conducted among patients with coronary heart disease and myocardial infarction by Friedman and Rosenman from the Harold Brunn Institute in San Francisco led to the development of the concept of so-called Type A Behavior Pattern (TABP), also referred to as Type A personality. The authors of the concept came to the conclusion that coronary heart disease patients exhibited a specific pattern of behavior in the premorbid period. At the end of the 1950s, the first description of TABP appeared in the literature, which has over the years been repeatedly modified, supplemented and enriched with new, more accurate characteristics. Type A individuals engage in achieving as many goals as possible in the shortest possible time. They are competitive and success-driven; they crave recognition and want to be promoted to higher positions; they are also mentally and physically vigilant, move briskly and have a firm handshake. They speak fast and loud in concise and clear sentences. They are often gruff and curt in their responses („yes", "never", "definitely”) and tend to control and interrupt the conversation. They often react emotionally to other people's words and chime in with their own remarks. They can react vehemently to questions concerning things like queuing ("Are you in line?"). During a conversation, they often have clenched fists or point a finger at the person they are talking to. They can be hostile towards their interlocutors $[3,4,17]$.

A behavior pattern that is opposite to TABP has been called by Friedman and Rosenman Type B Behavior Pattern (TBBP). Type Bs are not excessively ambitious; they do not compete with others, are easily contented with what they have, do not hurry, are laid back, and are generally happy to "go with the flow" rather than "make waves" [17].

In 1995, Johan Denollet, a clinical psychologist from the University of Tilburg in the Netherlands, introduced into scientific literature the concept of D-type personality defined as distressed or prone to stress. According to Denollet, type $\mathrm{D}$ personality consists mainly of two fixed dimensions: negative affectivity and social inhibition. Negative affectivity is a predisposition to experience strong negative emotions such as depressed, or even depressive, mood, anxiety, anger, irritation and hostility. Type D personalities have a negative self-image and very often report somatic complaints. They exhibit a constant tendency to withdraw from social life, i.e. they have an avoidant interpersonal style and try to avoid the potential threat resulting from social interactions. They fear disapproval, always feel uneasy, are tense, and lack a sense of personal security. They show a strong tendency to worry and feel tension and have a pessimistic outlook and a sense of being unhappy; type Ds are also shy, prone to self-blame, uneasy in the company of other people; they are reluctant to share their emotions, mainly for fear of disapproval and rejection. Type $\mathrm{D}$ personality is associated with symptoms of mental distress, such as reduced well-being, low self-esteem, low satisfaction with life, fatigue, helplessness in response to stress, a sense of hopelessness, and a tendency to become depressed. People with type $\mathrm{D}$ personality are fully aware of their emotions and being in stress. They are at risk of developing burnout syndrome; they may also feel emotionally exhausted and have a low sense of personal achievement [18].

Type A and D personalities show some similarities, but also differences. The emotions of anger and hostility are characteristic of both types. However, while Type As readily act out these emotions, type Ds tend to conceal 
them and refrain from expressing them. Both Type A and D personalities experience a lot of stress, but in Type Ds stress is primarily associated with social interactions. In type As, on the other hand, stress mainly results from the desire to control the situation and the people around them. Both types are reluctant to seek assistance and support from others in difficult situations. In addition, people with type $\mathrm{D}$ personality are prone to respond to stress with a sense of helplessness and hopelessness. If they constantly experience stress in the workplace, they run an increased risk of experiencing occupational burnout. The type D behavior pattern favors the occurrence of numerous somatic diseases, including cardiovascular diseases, mainly ischemic heart disease $[18,19]$.

\section{STRESS IN CARDIOVASCULAR DISEASE}

Stress, as the term is popularly understood, has long been associated with cardiovascular diseases, especially with a sudden onset heart attack. Stress is an inseparable element of our everyday lives. The leading causes of stress include the hectic pace of life, role overload, constant time pressure limiting contacts with family and friends, a competitive work environment, and too short rest periods or no rest at all.

Stress motivates people to act and cope with difficult life situations, and is an important stimulus encouraging individuals to respond to challenges in their professional and creative work. Recent studies have shown that in everyday life, increased stress levels play an important role in the pathophysiology of coronary heart disease [20, 21.

From the point of view of the relationship between stress levels and cardiovascular diseases, stress can be divided into acute, subacute and chronic. Acute stress can be caused by traumatic life events such as bereavement. An accumulation of stressful events, such as sitting examinations, giving a conference presentation, travelling, etc. is referred to as subacute stress. Stress experienced every day in the workplace is called chronic stress [22].

Many authors have demonstrated that chronic and subacute stress cause elevated blood pressure and activate neurohormonal pathways responsible for the development of atherosclerosis and its sequelae. Increased blood levels of norepinephrine lead to an increase in total peripheral resistance, vascular endothelial dysfunction, increased platelet activation and impairment in carbohydrate metabolism. These, in turn, lead to serious clinical consequences such as hypertension, myocardial infarction, strokes, arrhythmias and thrombosis [23, 24].

The results of research on work-related stress carried out by numerous authors over the past thirty years point to a strong relationship between the level of stress people experience at work and the risk of coronary heart disease. Six-year observations carried out in the 1980s by Karasek et al. showed that stress was associated with a four-fold increase in the risk of death from cardiovascular diseases [25].

A recent report by Chandola et al. showed that workplace stress was an important risk factor for an acute coronary event in $30 \%$ of men after myocardial infarction. The emotion that the male subjects felt most strongly when they were performing their work duties was the stress associated with work overload. In the group of female subjects, $24.7 \%$ reported that stress in the workplace was associated with the atmosphere at work and relations with their colleagues and superiors. The authors of that study also found that stress intensified with years of work experience [26, 27].

Nowadays, people are exposed to more and more stress factors as they experience stress in the workplace and in the family. Everyone goes through various failures; people experience financial difficulties, lack of fulfilment at work, and bad or depressed mood, which sometimes even leads to depression. Many people are burdened with the responsibility of looking after others, e.g. a disabled child or an elderly parent. These are stress factors that can cause, among others, increased blood pressure, increased heart rate, arrhythmias, and be one of the causes of inflammation of the vascular endothelium [28].

In clinical practice, cardiologists distinguish a disease entity known as "broken heart syndrome", i.e. stress-induced cardiomyopathy or takotsubo syndrome. The etiology of this syndrome is not entirely known, but the underlying cause of the disease is severe mental and physical stress. It is strong stress that impairs the function of coronary microcirculation and causes the release of catecholamines as well as an increase in their concentration in the blood. It is assumed that such a mechanism can cause cardiomyopathy. Strong stressors include such difficult life situations as bereavement, illness, serious financial problems, natural and traffic disasters and accidents at work [29].

\section{DEPRESSION, DEPRESSED MOOD AND ANXIETY}

The relationship between symptoms of depressed mood, depression and anxiety has been observed since ancient times. The first references to it were found in the works of ancient doctors and philosophers. Scientific observations of and research on the relationship between depression and cardiovascular diseases began at the end of the 1970s and in 1980s. One of the first studies on the relationship between depression and heart disease is Malzberg's report. The author recorded the mortality of patients with involutional depression in New York state hospitals and compared it with the mortality of the general population of this state. He showed that mortality from depression was similar to that of people with heart disease. The period of World War II and the difficult post-war situation in many countries postponed research in this area until the seventies. In 1979, in Denmark, Weeke published a study on mortality in patients diagnosed with unipolar and bipolar disorder and analyzed the causes of mortality. He found that more than $50 \%$ of the subjects had died of cardiovascular diseases [30, 31].

In the nineties, the impact of depression on the occurrence of coronary heart disease became the subject of interest of researchers in many countries, among others in the United States, Canada, Finland, Denmark and Poland [32].

Currently, in everyday clinical practice, medical teams deal with patients who have both heart diseases and depression. A team of German scientists from the Technical University of Munich, the Helmholtz Center Munich and 
the German Center for Cardiovascular Diseases led by Karl-Heinz Ladwig analyzed data collected over 10 years from 3428 men aged 45-74. The analysis concerned male patients only because women up to 65 years of age suffer less often from cardiovascular diseases. However, according to Ladwig, the results of his team's study are valid for women, who suffer from depression more often than men. The results published by the Munich scientists indicate that depression can be as serious a risk factor as the previously identified risk factors. Those researchers argue that depression should be included among the most important increased-risk factors for cardiovascular diseases, side by side with high cholesterol levels, obesity, hypertension, smoking, and diabetes [33].

Krupka-Matuszczyk reports that the risk of developing coronary heart disease is twice as high in people diagnosed with an episode of depression. It has also been found that depression is a stronger increased-risk factor for developing a heart disease than hypertension, increased cholesterol levels, diabetes and substance abuse. The probability of developing coronary heart disease, including myocardial infarction, is 1.5 to 5 times higher in patients with depression compared to people without an episode of depression. Patients with depression after myocardial infarction are less likely to quit smoking, do not follow a diet, neglect physical activity, and do not regularly adhere to their hypertension, diabetes, and cholesterol medications [34].

Scientific reports have indicated that depression may have a more direct effect on the cardiovascular system. An important element in the development of atherosclerosis and the onset of a heart attack is inflammation of the arterial walls. Depression works on blood vessels through stress hormones which cause metabolic changes. The consequence is chronic inflammation that changes blood vessels and promotes excessive thrombotic activity. This mechanism can lead to thrombosis [32, 33].

Patients with depression show a greater tendency for platelets to clump together, i.e. to form clots that can lead to a heart attack when they close the lumen of an artery. The walls of blood vessels are lined with a layer of closely packed cells (the so-called endothelium) that prevent the formation of blood clots. Persons suffering from depression have shown abnormal function of these cells [33].

It is estimated that $1 / 5$ of patients with cardiovascular diseases have co-morbid depression. Depression is more prevalent in hospitalized patients, rather than outpatients, and in men suffering from cardiovascular diseases. Depression can develop at any stage of a cardiovascular disease, as a reaction to a sudden cardiac incident, a badly prognosticating diagnosis, the need to stay in hospital, treatment and convalescence, or the need to change one's lifestyle and restrict activity. Apart from biomedical factors, the occurrence of depression is influenced by stress related to the disease, lack of emotional support, social isolation, and poor living conditions. Depression increases the number of complications and costs of treatment, and weakens psychosocial efficiency. Depression significantly increases the mortality of patients after myocardial infarction, patients after coronary artery bypass surgery with no complications prognosticated, patients with stable coronary disease and patients with heart failure, regardless of its etiology [34, 35].

Symptoms of depression and depressed mood are usually accompanied by restlessness turning into anxiety. Anxiety sometimes takes the form of panic with severe symptoms of psychomotor agitation. In such cases, patients report numerous somatic complaints, such as chest pains muscle tremors, headache and dizziness, excessive sweating, feeling of general weakness, loss of control over their body, and the sensation of dying. Patients often experience anxiety, which they describe as expecting a sudden, potentially dangerous and life-threatening event. The threat they expect is only imaginary, because there is no immediate danger to their health or life. They are usually unable to determine the nature of the anticipated threat, but state that they are afraid for their lives and are feeling very unwell. The fear for health and life the patients experience is an existential fear $[36,37]$.

A five-year study conducted among 114 patients after myocardial infarction who had undergone multi-stage rehabilitation showed that throughout this period the patients' mood had remained slightly depressed. A high level of internal tension was present in the structure of uneasiness and anxiety in those patients, and the levels of uneasiness and anxiety were always close to the neurotic level. Depression and anxiety constitute a serious medical problem in cardiovascular diseases and, if left untreated, can lead to significant health consequences [16].

Psychological risk factors are features related to the position of the individual in society, as well as the mental states or disorders related to this position, such as low self-esteem, stress related to work, personal life and family relationships, lack of social support, depression, anxiety, or type $\mathrm{D}$ personality, which is pessimistic and prone to social withdrawal.

A low socioeconomic status is usually associated with a low level of education, low income, very often unprofitable work, poor housing conditions, poor lifestyle, bad eating habits, heavy smoking, and a lack of physical activity. Social isolation and a lack of social support may constitute obstacles to compliance with recommended treatment [38].

One of the most important psychosocial risk factors is work-related stress. Most often, chronic tension and stress is caused by conflicts in the workplace with superiors and colleagues. Superiors often place too high demands on employees, who are unable to meet them, among others due to improper organization of work, bad atmosphere and time pressure. This potentially leads to uncertainty about further employment. Negative emotional states, such as anger, hostility, and aggression caused by stressful situations in the workplace are transferred to the family home and can cause family conflicts. Psychosocial factors do not occur singularly, but they usually accumulate in the same people or groups of people, e.g. with individuals with a low socioeconomic status [39, 40].

Social support plays an important role in undertaking intervention measures aimed at counteracting the 
psychosocial risk factors of diseases, and in promoting a healthy lifestyle. It has a significant impact on health and health-related behaviors. Positive relationships with others help relieve the physical symptoms of the disease, promote faster recovery, encourage patients to undergo rehabilitation and resume physical activity, help alleviate negative emotional states, play a role in building empathic relationships with friends and the medical team based on mutual understanding and trust, and facilitate adaptation to changes in the patients' lifestyle and philosophy of life.

Over 60 years have passed since the earliest studies on risk factors for cardiovascular diseases, but those factors still remain a significant problem for modern medicine and health sciences. Numerous studies conducted around the world indicate that risk factors for heart attack are similar for all nations regardless of race, region of the world, or latitude.

Population-focused programs devoted to health promotion and informing the general public about the risk factors for cardiovascular diseases should mainly aim at improving people's lifestyle, in particular with regard to nutrition, smoking, alcohol consumption, physical activity and mental well-being.

\section{CONCLUSIONS}

1. In countries with a high prevalence of cardiovascular diseases, including Poland, recommendations for improving lifestyle ought to be addressed to the entire population.

2. They should be disseminated through mass media and public institutions, such as radio, television, press, scientific publications, schools, and local government and social organizations.

3. Health care institutions are important opinion-forming bodies which play, and should continue to play, a role in initiating health promoting actions and disseminating knowledge on cardiovascular diseases and their risk factors.

4. Change of lifestyle and elimination of risk factors, including situations causing chronic stress, are a priority in the recommendations of the Polish Forum for Prevention of Cardiovascular Diseases.

\section{REFERENCES}

1. Friedman M, Rosenman R. Association of specific overt behavior pattern with blood and cardiovascular findings; Blood cholesterol level, blood clotting time, incidence of arcus senilis and clinical coronary artery disease. JAMA 1959;169:1286-1296.

2. Rosenman R, Friedman M, Straus R, Wurm M, Kositchek R, Hahn W, Werthessen N. A predictive study of coronary heart disease:The Western Collaborative Group Study. JAMA 1964;189:15-26.

3. Rosenman R, Friedman M, Straus R, Jenkins C, Wurm M. Coronary heart disease in The Western Collaborative Group Study. A follow-up experience of 4.5 years. J Chron Dis. 1970;23:173-190.

4. Rosenman R, Brand R, Sholtz R, Friedman M. Multivariate prediction of coronary heart disease during 8.5 year follow-up in the Western Collaborative Group Study. American Journal of Cardiology. 1976;37:903-910.
5. European Guidelines on cardiovascular disease prevention in clinical practice (version 2016). The Fifth Joint Task Force of the European Society of Cardiology and Other Societies on Cardiovascular Disease Prevention in Clinical practice. Eur Heart. J. 2016;37:2315-2381.

6. Solberg LA, Strong JP. Risk factors and atherosclerotic lesions. Atherosclerosis. 1983;3:187-198.

7. Stępińska J. Czynniki ryzyka choroby wieńcowej-sprawozdanie z badań Krozinger (RFN). Kardiol Pol. 1990;33:57.

8. Podolec P, Jankowski P, Zdrojewski T, et al. Polish Forum for Prevention Guidelines on Cardiovascular Risk Assessment: update 2016. Kardiol Pol. 2017;75:84-86.

9. Cooney M, Vartiainen E, Laatikainen T, De Bacquer D, Mc Gorrian C, Dudina A, Graham I. Cardiovascular risk age: concepts and practicalities. Heart 2012;98:941-946.

10. Leening M, Ferket B, Steyerberg E, et al. Sex differences in lifetime risk and first manifestation of cardiovascular disease: prospective population based cohort study. BMJ 2014;349:5992.

11. Janion M. Epidemiologia chorób układu krążenia u kobiet. In: Kornacewicz-Jach Z, Janion M (eds). Choroby serca u kobiet. DUET, Kielce 2015, pp. 149-162.

12. Undas A, Szczeklik A, Cybulska B, et al. Miażdżyca i ryzyko sercowonaczyniowe. In: Szczeklik A (eds). Interna Szczeklika, Medycyna Praktyczna, Kraków 2015, pp. 148-155.

13. Jankowski P, Czarnecka D. Ocena i kontrola czynników ryzyka chorób sercowo-naczyniowych w profilaktyce pierwotnej. In: Dąbrowski R, Szwed H.(eds). Farmakoterapia chorób serca w podstawowej opiece zdrowotnej. Termedia, Poznań 2019, pp. 3-13.

14. Łazowski J, Płużek Z. Problemy psychosomatyczne w pierwotnym nadciśnieniu tętniczym i chorobie wieńcowej. PZWL, Warszawa 1982.

15. Juczyński Z. Predykatory efektywności rehabilitacji kardiologicznej po niepowikłanym zawale serca. Pol Tyg Lek. 1987;42:721-724.

16. Nasiłowska-Barud A. Zmiany psychosomatyczne u chorych po świeżym zawale serca w okresie pięcioletniej rehabilitacji. Agencja WydawniczoHandlowa AD, Lublin, 1996.

17. Wrześniewski K. Styl życia a zdrowie. Wydawnictwo Instytutu Psychologii PAN, Warszawa, 1993.

18. Ogińska-Bulik N. Osobowość typu D a występowanie chorób somatycznych. Szt Lecz. 2004;10:9-16.

19. Basińska M, Andruszkiewicz A. Cechy osobowości typu D a funkcjonowanie w chorobie pacjentów ze schorzeniami przewlekłymi. Pol Forum Psycholog 2016;2:221-237.

20. Kośmicki M. Stres psychospołeczny jako czynnik ryzyka choroby wieńcowej. Przew Lek. 2002;6:28-37.

21. Vaccarino V, Bremner JD. Behavioral, emotional and neurobiological determinations of coronary heart disease risk in women. Neurosci Biobehav Rev. 2017;74:(Pt B):297-309.

22. Vanitallie T. Stres: A risk factor for serious illness. Metabolism. 2002;51:40-45.

23. Vujcic T, Vlajinac H, Dubljanin E, et al. Psychological stress and risk of myocardial infarction: A case-control study in Belgrade (Serbia). Acta Cardiol Sin. 2016;32:281-289.

24. GuzińskaK,KupcA,BorysB.Zasobyodpornościnastreswprocesiezdrowienia u pacjentów z chorobą niedokrwienną serca. Psychiatria 2007;4:144-152.

25. Karasek R, Baker D, Marxer F, Ahlbom A, Theorell T. Job decision latitude, job demands, and cardiovascular disease: a prospective study of Swedish men. Am J Pub Health. 1981;71:694-705.

26. Chandola T, Britton A, Brunner E, Hemingway H, Malik M, Kumari M, Badrick E. Work stress and coronary heart disease: What are mechanisms? Eur Heart J. 2008;29:640-648. 
27. Kivimäki M, Virtanen M, Elovainio M, et al. Work stress in the etiology of coronary heart disease - a meta-analysis. Scand J Work Environ Health 2006;32:431-442.

28. Bartkiewicz A (eds). Choroby układu krążenia w aspekcie pracy zawodowej. Oficyna Wydawnicza Instytutu Medycyny Pracy, Łódź2011, pp. 5-177.

29. Schneider B, Athanasiadis A, Schwab J, et al. Complications in the clinical course of tako-tsubo cardiomyopathy. Int J Cardiol. 2014;76:199-205.

30. Eaton W. Medical and psychiatric comorbidity over the course of life. American Psychiatric Publishing, Washington, 2006.

31. Berkman L, Blumenthal J, Burg $M$, et al. Effects of treating depression and low perceived social support on clinical events after myocardial infarction: The Enhancing Recovery in Coronary Heart Disease Patients (ENRICHD) Randomized Trial. JAMA 2003;18(289):3106-16.

32. Frasure-Smith N, Lesperance F, Talajic M. Depression and 18-month prognosis after myocardial infarction. Circulation 1995;91:999-1005.

33. Ladwig K H, Baumert J, Marten-Mittag B, et al. Room for depressed and exhausted mood as a risk predictor for all-cause and cardiovascular mortality beyond the contribution of the classical somatic risk factors in men. Atherosclerosis 2017;257:224-231.

34. Krupka-Matuszczyk I. Depresja w chorobach serca. Kardiologia po Dyplomie 2012;11:57-61.

35. Matysiakiewicz J, Pudło R. Mechanizmy łączące depresję i zdarzenia sercowe. Lęk i Depresja 2006;11:281-291.

36. Nemeroff CB, Musselman DL, Evans DL. Depression and cardiac disease. Depress Anxiety 1998;8(Supp.1):71-79.

37. Celano Ch, Daunis D, Lokko H, Campbell K, Huffman J. Anxiety disorders and cardiovascular disease . Curr Psychiatry Rep. 2016;18:101-110.

38. Salska A, Chiżyński K, Salski W, Wiszniewska M, Walusiak-Skorupa J. Choroby układu krążenia związane z pracą zawodową istotny - problem zdrowotny osób pracujących. Chor Serca Nacz. 2015;12:75-87.
39. Modrzejewski W, Musiał W. Stare i nowe czynniki ryzyka sercowonaczyniowego - jakzahamować epidemię miażdżycy? Częśćl. Klasyczne czynniki ryzyka. Forum Zab Metabol. 2010;1:106-114.

40. Modrzejewski W, Musiał W. Stare i nowe czynniki ryzyka sercowonaczyniowego - jak zahamować epidemię miażdżycy?. Częśćll. Forum Zab Metabol 2010;1:168-176.

\section{ORCID and contributioship:}

Alicja Nasiłowska-Barud - 0000-0002-5707-2238 ${ }^{A, B, C, D, E, F}$

Małgorzata Barud - 0000-0002-3734-2421 A,C,E,F

\section{Conflict of interest}

Authors declare no conflict of interest

\section{CORRESPONDING AUTHOR}

Alicja Nasiłowska-Barud

The Department of Clinical Psychology

Medical Uniwersity in Lublin

Chodźki str. 7, 20-093 Lublin

tel.: 81-72-44-327, 81-448-68-62

e-mail: alicja.nasilowska-barud@umlub.pl

Received: 06.07 .2020

Accepted: 07.09.2020

A - Work concept and design, B - Data collection and analysis, C - Responsibility for statistical analysis, D-Writing the article, $\mathbf{E}-$ Critical review, $\mathbf{F}-$ Final approval of the article 